Andrea Tomaskova,

Ph.D., University of Finance and Administration, Czech Republic

ORCID ID, 0000-0003-1547-2759

email: tomaskova.andrea@mail.vsfs.cz

Roman Smietanski,

Ph.D., Opole University of Technology, Poland

(iD) ORCID ID, 0000-0002-9255-5665

email: r.smietanski@po.edu.pl

Miroslav Halouzka,

University of Finance and Administration, Czech Republic

email: 37039@mail.vsfs.cz

Correspondence author: tomaskova.andrea@mail.vsfs.cz

\title{
THE INTERDEPENDENCY BETWEEN A FAMILY COMPANY'S NAME AND A FAMILY NAME
}

Abstract. A company's name often personifies the company. In the case of family companies, the name is mainly connected with that of the owning family. This paper aims to identify and substantiate the context of the perception of any possible risks from the association of a family name with that of a family company during the generational exchange with the participation of several generations in the family company's management. The hypotheses have been verified based on the evaluation of data acquired from a sample of 245 respondents from the Czech Republic. The research period is 2017-2019. The qualitative research is based on round discussion tables with family business owners. The data has been processed using correlation and regression analysis. The authors have shown that owners consider the association of the family name with that of a family company to be a potential risk. Any negative regard for the family company and the family could lead to losing the family's good name and the company and losing customers and employees. Moreover, it could damage the process of intergenerational transition. The connection between the intensity of the risk perception and the generational exchange process with the participation of several members in the management of a family company has been statistically demonstrated. The degree of perception of the risk is high in family companies where the generational exchange is still ongoing. The exclusion of the variable of the connection of a family company name with the owning family due to collinearity suggests a possibility for a different type of research that would demonstrate the statistical significance. The unique article nature lies in the fact that it involves research into the current, real process of generational exchange taking place in Czech family companies with mainly two generations and up to three generations in the family company management.

Keywords: company name, correlation analysis, Czech Republic, family business, family name, generations, intergenerational transfer, regression analysis.

Introduction. The phenomenon of the family company has been the subject of theoretical and empirical studies undertaken by many universities, associations, and state entities (Benavides-Velasco, 2013). The topic of family companies is taught separately at universities and is very often the subject of seminars for state institutions and private companies. These entities often cooperate.

According to the Family Firm Institute, family companies create $70-90 \%$ of world GDP and $60-80 \%$ of employees. They are more resistant to crises and are based on a high degree of responsibility concerning the environs. Investments in family firms remain in the regions and constitute the basis for the services provided there. Family companies try to balance the family's needs with the business's needs. Besides, they give preference to socio-economic wealth over a narrow focus on financial objectives (MPO, 2019b). The family companies concentrate economic power and transfer it to the following generations, which are

Cite as: Tomaskova, A., Smietanski, R., \& Halouzka, M. (2021). The Interdependency Between a Family Company's Name and a Family Name. Marketing and Management of Innovations, 2, 115-132. http://doi.org/10.21272/mmi.2021.2-10 
then required to develop it further (Means, 2016) and resolve the state's economic and social problems (Aries, 2016). More and more scholars from different circles interest in the family businesses issue (Mura, 2020). Family companies play a significant role in the country's economy and contribute to creating the national business environment substantially (Kroslakova, 2020; Orgonas et al., 2020). The family company is an entity that could be found worldwide, for example, Spain, Austria, Italy, Germany, and typical EU countries with high levels of family companies (Petlina and Korab, 2018). To monitor family companies and subsequently evaluate their impact on the economy, they must be legally defined and characterized in legislation (MPO, 2019b).

The issue of family companies has been thoroughly analyzed by several researchers both historically and at present who have concerned themselves with the influence of newly arriving generations in family company management (Meneses et al., 2014; Adedayo et al., 2016). The individual generations create a positive brand image over the long term, transfer their knowledge and know-how, verify the quality of the products on offer, and secure the growth of the family company (Alonso and O'Brien, 2017; Aparicio et al., 2017; Bakoglu and Yıldırım, 2016). The originality of this article lies in the following facts. The first intergenerational transfer of family companies to the upcoming generation in modern history is currently taking place in the Czech Republic. Several generations are currently active in family companies at various levels of involvement in this period. The connection of the family with the company is accentuated more than ever during this process. For external and internal entities, this could implicate a future need for capital for intergenerational transfer. In the environment of the Czech Republic, the generation change according to the intergenerational division is also unique because this is historically the first exchange of generations after the communist period. This article has been structured using the classic concept for a scientific paper. The submitted literature review serves as a literary entry point into the perception of the issue at hand. It is followed by a statement on the scientific methods used in work and assessing the outputs. The paper closes with a discussion, a list of its limitations, and some proposals for future research.

Literature Review. Family-owned and/or family-managed businesses control the economic landscape throughout the world. The fundamental principles of family companies include loyalty, honesty, and the ability to motivate the people in one's environs. Family companies continue to generally respect whatever their founders achieved, including long after their death (Kenyon-Rouvinez et al., 2016). According to Darier Hentsch, children who grow up in a family that owns a family company know that family companies are not businesses or even families like all the rest. That could be compared to a situation where a person knows a language without ever learning its grammar. Family companies are distinguished more than ever by a «human face». Behind the human face, they see a more truthful picture of the values of their founders and the people who transfer them from generation to generation (KenyonRouvinez et al., 2016). The face of the business owner or founder, i.e., the face of a specific person, is behind the face of a family business. Family companies are better known in the regions if there is «someone visible» on their behalf (Schmidts and Shepherd, 2015). The most significant theme in their business is passion and intrinsic motivation (Smith, 2020).

Every family company is a combination of three spheres such as business, family, and ownership. They include the material aspect (ownership), the rational aspect (business), and the emotional aspect (the family). These aspects are interlinked to a maximum extent and are almost inseparable (Taguiri and Davis, 1982). Activities aimed at increasing the attractiveness would lead to an increase in spending of the business area and, by analogy, to a rise in macroeconomic indicators (Gavurova et al., 2020). This connection brings both positive and negative aspects. A family company's bad reputation reflects poorly on the family and vice versa. It is not by chance that many family companies have been named after their founders (for example, Walmart after Sam Walton, Forbes after BC Forbes). The choice of the name clearly shows the company's family element. Recent studies have shown that this type of eponym, which uses the owner or the owner's surname in the company brand, has a positive impact on sales turnover 


\section{A., Tomaskova, R., Smietanski, M., Halouzka. The Interdependency Between a Family Company's Name and a Family Name}

and the company's performance (Kashmiri and Mahajan, 2010). The name of the founder family as part of a family company's name acts as a valuable company resource that increases the yields from shares (Kashmiri and Mahajan, 2014). On the other hand, any scandal or public mistrust in a family company is reflected on the individuals or family members instead of anonymous shareholders. However, that often creates even greater pressure on family members to cooperate to avoid any negative attention and increase the brand's trustworthiness (Kashmiri and Mahajan, 2010; Kashmiri and Mahajan, 2014; Ball, 2017). Identifying the family name with the company motivates the family members to maintain a favorable reputation, increasing their socio-emotional wealth. Likewise, Deephouse and Jaskiewicz (2013) claimed that a company's reputation is higher if the family name is included in the company name. The family members are motivated to ensuring that the company has the best reputation. The level of family ownership should be associated with a more favorable reputation (Basco, 2017). A family's identity and reputation are closely associated with a family company's image, influencing branding and marketing (Babin et al., 2017, Astrachan et al., 2019). However, not all family companies use their surnames as part of the company name. Companies using the family surname in their name have a distinctly higher level of marketing, place a great deal of emphasis on creating value and perform better than companies that do not use the family surname in their name (Kashmiri and Mahajan, 2010). However, all these aspects are connected with traditions, history, the family name, and a specific face and come with negative connotations, threats, and risks.

The risk factors for family companies have been the subject of research undertaken by many international authors. Family companies may be generally risk-averse for several reasons. Being riskaverse is often considered a positive characteristic in family companies, but it could also lead to conduct that endangers its long-term existence (Hiebl, 2012). The most significant risks for family companies lie in the company's unclear role in the company and lack of communication (Lipitz and Hauser, 2016). The owners of family companies perceive any overlap of competencies and absence of communication as highly negative regarding the possible damage it may cause to the name of the family company and the family itself. The most significant risks faced by family companies include problems with succession and those who damage the family's reputation (Dipietro, 2015). Most family companies are facing the situation where an intergenerational transfer is either ongoing or about to occur. Failure constitutes a risk for both the family and the company (Petru et al., 2018). An insufficiently managed process of generational exchange poses a threat to both the owner and the successor and harms the family's assets and may damage family relationships and social ties, and lead to a loss of social standing (Servus et al., 2018). Misunderstood and unmanaged risks could be dangerous for both the entire family and the company (Daniell and McCullough 2013). Inaction in the area of risk management could result in a loss of assets and jobs and may even endanger the future existence of the family company. This risk is significant in family companies where many family members participate in the company or are dependent upon it (Crystal, 2015). The family has to deal with the most challenging risks concerning concern-sensitive questions about family relationships and reputation (Downing, 2012). According to Daniell and McCullough (2013), there are also «soft» risks for family businesses, such as personal family disputes, competition for the leading position in the family and court, and marital disputes among family members. Altruism and nepotism damage the effectiveness of a family company, and favoring family members at the expense of qualified employees in the company cast a bad light on the family itself (Firfiray et al., 2018). Notably, Kupec et al. (2020) favor increasing the employees' personnel competencies.

Many family companies fail because the family members do not undertake steps in the area of risk management. It is difficult to maintain family companies for the next generation without assessing the direct levels of risk. Some risks are foreseeable, while others could be unique to a specific family, such as the risk of family disputes, risks associated with the non-existence of a plan for transferring a real estate, or the management of inheritances. In turn, some risks could not be quantified financially and represent a 
threat to the family company's ongoing competitiveness (Visser and van Scheers, 2018). A threat could arise from an unclear relationship between the organizational culture and the company orientation (Cherchem, 2017) during the implementation of innovations and new technology (Cucculelli et al., 2016) or in the case of failure of the transgenerational exchange (Daspit et al., 2016). The loss of key employees could cause serious business losses (Pekerşen and Tugay, 2020). A significant part of any risks comes from unresolved conflicts (De Clercq and Belausteguigoitia, 2015), with information asymmetry during decision-making (Dehlen et al., 2014), upon the exit of the founder and due to a missing or insufficient strategy for the realization of marketing activities (Petru et al., 2020). Implementing risk management strategies as a long-term interactive process that must be continuously improved and whose individual steps must be integrated into family company management is essential (Di Serio et al., 2011). The authors are offered a research gap for the given areas concerning the involvement of representatives of the participating generations, emphasizing linking the name of the company name and the family's name.

Methodology and research methods. This paper aims to identify and substantiate interdependencies in the perception of any possible risk from the association of a family name with that of a family company during generational exchange involving the participation of several generations in the family company management.

The following three hypotheses $(H 1, H 2$, and $H 3$ ) and five research questions (RQ 1, RQ 2, RQ 3, RQ 4 , and $R Q$ 5) have been established to fulfill the research's objective.

$\mathrm{H} 1$ : The family company name is connected with a risk that could arise from the association of the family name with that of the family company.

$\mathrm{H} 2$ : The owners of family companies where several generations are in management are more aware of the risk of associating the family name with that of the family company than is the case where only one generation in the family company's management.

H3: The owners of family companies perceive a risk from associating the family name with the family company name during the generational exchange process.

$\mathrm{RQ}$ 1: Is the family name part of the family business's name?

$\mathrm{RQ} 2$ : Which family company name is preferred concerning the owning family?

$R Q$ 3: Do the owners of family companies perceive any risks in associating their family name with that of their family business?

$\mathrm{RQ}$ 4: Do the owners of family companies perceive more risks from associating the family name with that of the family company in those family companies that are undergoing generational exchange?

$R Q 5$ : Do the owners of family companies perceive a greater risk from associating the family name with that of the family company in those family companies where several generations are involved in management?

The research questions would be answered upon the basis of descriptive statistics. In turn, the hypotheses would be confirmed/refuted based on correlation and regression analysis.

The sources of data - Family companies have been defined as follows. Definition of the family business: A family business is a family business corporation or a family trade.

1. Family Business Corporation is a business corporation where more than one-half of its members are family members. At least one member of that family is its statutory body or where members of one family directly or indirectly exercise most voting rights. Besides, at least one member of that family is a member of the statutory body of this business corporation. Family Business Corporation is also considered to be a business corporation where most of the voting rights are exercised in favor of one family by the trust fund or its trustee provided that at least one member of the family is a member of the statutory body of trust fund or a trustee of the trust fund. 
2. A family business is a business where at least two members of one family participate in their work or property, and at least one of the family members holds a trade or other similar authorization or is entitled to do business for another reason.

3. The members of one family in the family business are considered jointly working spouses or partners, or at least one of the spouses or partners and their relatives up to the third degree, persons with spouses or brothers- and sisters-in-law up to the second degree, as well as related persons in direct line or siblings. If a person, who is underage or not fully legally competent, is among them, it should be represented in voting by a legal guardian (MPO, 2019a).

It is necessary to note this does not involve a random selection. Given the nature of the problem being researched (especially the unknown character and size of the population, which are generally the Czech family businesses), it has been necessary to use data from the database of family companies maintained by the University of Finance and Administration. Secondary data from publicly accessible sources were processed to identify the companies (the company name, address, legal form, contact information, addresses were verified). Primary data (the derivation of the company name, the number of generations working in the company, the perception of the risks associated with connecting the family name with that of the company) was acquired from the participants at discussion roundtables.

The procedure for selecting the investigated sample was as follows:

1. The database of family companies, which has been kept at the University of Finance and Administration since 2015, contained 3622 corporate entities at the beginning of the research.

2. Family companies, for which the necessary primary data was fully available, were selected.

3. Of these family companies, those that participated at the discussion roundtables were purposefully selected - the data was acquired for the Risk variable.

4. The work was undertaken with a sample of 245 family companies. According to European Family Businesses, expert estimates showed that family businesses in the Czech Republic make up $87 \%$ of all business entities - more than 450 thousand family businesses. It is essential to note that it is difficult to estimate how many family businesses are actually due to the statistical data absence. There is no unifying register or database of family businesses.

The family companies often include the family surname in their names. This connection brings both positive and negative aspects. This research focussed on a negative aspect, i.e., the risk of connecting a family name with a family company.

The research methodology. The research used the method of secondary data analysis and the qualitative inquiry at discussion roundtables. Four variables were chosen for this research:

1. the legend of the family company's name - «legend» (Table1);

2. the risk of threats to the good name of the family and the family company - «risk» (Table 2);

3. the process of generational exchange - «process»: not current, underway, transferred;

4. the generations active in the family company - "generations»: only 1st; 1 st and $2^{\text {nd; }} 1$ 1st, $2^{\text {nd }}$, and 3 rd; $2^{\text {nd }}$ and $3^{\text {rd }}$; only $2^{\text {nd }}$.

The data acquired by the research has been analyzed using descriptive statistics and regression and correlation analysis to demonstrate the interdependency of the variables and define the output model.

Table 1. Examples of the identification of family company names

$$
\text { Legend }
$$

An invented corporate name, including the company's legal form

The surname is included in the company name + possibly the company's legal form

The company name only consists of a name and a surname

Continued Table 1 


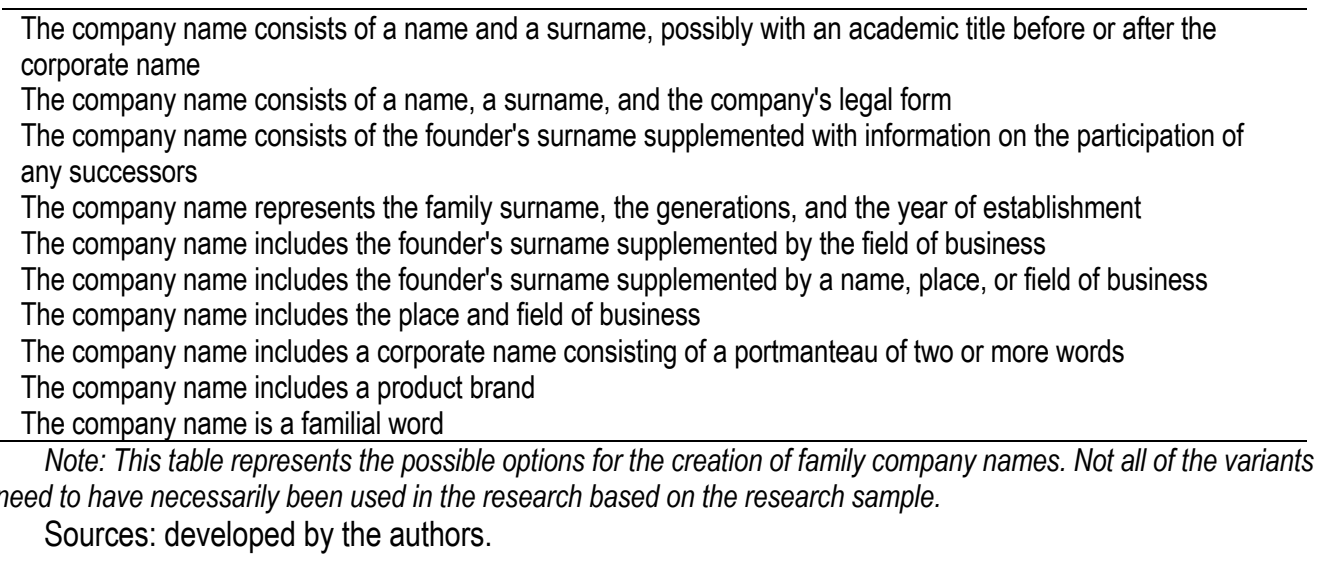

Table 2. The assessment scale for the «risk» variable

\begin{tabular}{ll}
\multicolumn{1}{c}{ Risk intensity } & \multicolumn{1}{c}{ Description } \\
\hline Without Risk & The owner does not admit to the threat to the business. \\
Low Risk & Threats from the exit of non-keys employees. \\
Middle Risk & Threats from the exit of key employees, customers, and suppliers. \\
High Risk & $\begin{array}{l}\text { Threats from the exit of employees, key customers, and suppliers. Threats and } \\
\text { impossibility of public activities, e.g., a municipal council member, the board of directors } \\
\end{array}$ \\
& of other companies, involvement in the non-profit sector, etc.
\end{tabular}

Note: According to the information of FB owners regarding the perceived risk, the description is.

Sources: developed by the authors.

The correlation analysis. Correlations in their various forms are the most frequent statistical characteristics found in the expert literature (Brom and Rehak, 2015). The goal of correlation analysis is to ascertain the mutual relationships that exist between the researched variables. The Pearson correlation coefficient, which measures the strength of a linear association between two variables, was used to ascertain the interdependency of the variables. That subsequently makes it possible to define the strength of the associations between the results of the investigated variables. According to Tran (2011), Person's coefficient is a parametric statistical test for determining the tightening relationship of variables. At values of the Person's correlation coefficient above 0.4 (minimum with one of the other variables), the linkage of the variables is significant for this research. At values above 0.7 , the linkage of the variables is interpreted as very important. The Pearson correlation coefficient is as follows:

$$
r=\frac{\sum_{i=1}^{n}\left(x_{i}-\bar{x}\right)\left(y_{i}-\bar{y}\right)}{\sqrt{\sum_{i=1}^{n}\left(x_{i}-\bar{x}\right)^{2}} \sum_{i=1}^{n}\left(y_{i}-\bar{y}\right)^{2}}
$$

where $\bar{x}$ and $\bar{y}$ are selection averages, and $\mathrm{s}_{\mathrm{x}}$ and sy are determinative selection deviations.

The results of the correlation analysis enable the confirmation or rejection of hypotheses $\mathrm{H} 1, \mathrm{H} 2$, and H3. The correlation analysis was processed using the IBM SPSS statistical program, ver. 25. The results of the correlation are set out in Table 9. The regression analysis. The regressive function $\eta$ can be written as follows: 
$\eta=\beta_{0}+\beta_{1} x_{1}+\beta_{2} x_{2}+\cdots+\beta_{m} x_{m}=\beta_{0}+\sum_{i=1}^{m} \beta_{i} x_{i}$

where $\beta_{0}, \beta_{1}, \beta_{2}, \ldots, \beta$ mare regressive parameters and $x_{1}, x_{2}, x_{3}, \ldots, x_{m}$ are explanatory variables.

The estimate of this regressive function is the selective (empirical) regressive function of the shape (3).

$$
Y=b_{0}+b_{1} x_{1}+b_{2} x_{2}+\cdots+b_{m} x_{m}=b_{0}+\sum_{i=1}^{m} b_{i} x_{i}
$$

A more straightforward way of analyzing the data is by Darlington and Hayes (2017) and Písař and Bilkova (2019). According to the linear regressive function, the findings would be fundamental to understanding how the researched variables have mutually influenced one another (Písař and Bílkova, 2019). The results of the regressive analysis are stated in Tables $9,10,11,12$, and 13 . Table 12 presents the model interpretation.

Results. The investigated N=245 sample was initially tested from the point of view of the completeness of the tested variables using the SPSS program. The analyzed sample was $100 \%$ compliant with the data completeness test. Descriptive statistics. The investigated family companies were founded within the range of years (Table 3). The information on the year of establishment is of significance from the point of view of generational exchange and the life cycle of the family company and the family.

Table 3. The year of establishment of the family company

\begin{tabular}{cccccccc}
\hline \multirow{2}{*}{ Year of establishment } & To 1989 & $\mathbf{1 9 9 0 -}$ & $\mathbf{1 9 9 5 -}$ & $\mathbf{2 0 0 1 -}$ & $\mathbf{2 0 0 6 -}$ & From & \multirow{2}{*}{ Total } \\
& incl. & $\mathbf{1 9 9 4}$ & $\mathbf{2 0 0 0}$ & $\mathbf{2 0 0 5}$ & $\mathbf{2 0 1 0}$ & $\mathbf{2 0 1 1}$ & \\
\hline Frequency \% & 1,6 & 33,9 & 18,4 & 20,0 & 12,2 & 13,9 & 100,0 \\
\hline
\end{tabular}

Sources: developed by the authors.

Most of the family companies were established between 1990-1994 and the following decade. These are precisely the family companies where the issue of generational exchange is current.

Each family company has its name, which has been created according to certain traits, characteristics, and considerations. Table 4 displays a summary of the family company according to the formation of their names. The results provide the answer to RQ1: What composition of the family company's name is preferred?

Table 4 shows that $43.2 \%$ of family companies include a component of the «familial» and a family name in their names. It provides a positive answer to RQ1: Is the family name part of the family business's name? Yes, it is. The most frequent composition of the family company's name provides the answer to $\mathrm{RQ2}$ : Which family company name is preferred concerning the owning family? $23.3 \%$ of family companies have the founder's surname and the field of business in their names. It is followed by $17.1 \%$ of family companies that have the founder's surname and the company's legal form in their names. It is possible to state that the family company's name is associated with the family name.

Positive and negative aspects and possible risks could arise from such an association. In turn, another part of the research focussed on the potential risks. At the discussion roundtables, the owners of the family companies expressed the degree of risk that they perceive from the association of their family company's name and that of the family.

Table 4. The frequency of the legend in the composition of company names

\begin{tabular}{lcrcc}
\hline \multicolumn{1}{c}{ Legend } & Frequency & Percent & Valid Percent & Cumulative Percent \\
\hline $\begin{array}{l}\text { An invented corporate name, including } \\
\text { the company's legal form }\end{array}$ & 60 & 24,5 & 24,5 & 24,5 \\
$\begin{array}{l}\text { The surname is included in the } \\
\begin{array}{l}\text { company name + possibly the } \\
\text { company's legal form }\end{array}\end{array}$ & 42 & 17,1 & 17,1 & 41,6 \\
\hline
\end{tabular}




\begin{tabular}{|c|c|c|c|c|}
\hline & & & & Continued Table 4 \\
\hline $\begin{array}{l}\text { The company name consists of the } \\
\text { founder's surname supplemented with } \\
\text { information on the participation of any } \\
\text { successors }\end{array}$ & 2 & ,8 & 8 & 42,4 \\
\hline $\begin{array}{l}\text { The company name represents the } \\
\text { family surname, the generations, and } \\
\text { the year of establishment }\end{array}$ & 1 & ,4 & ,4 & 42,9 \\
\hline $\begin{array}{l}\text { The company name includes the } \\
\text { founder's surname supplemented by } \\
\text { the field of business }\end{array}$ & 57 & 23,3 & 23,3 & 66,1 \\
\hline $\begin{array}{l}\text { The company name includes the } \\
\text { founder's surname supplemented by a } \\
\text { name, place, or field of business }\end{array}$ & 3 & 1,2 & 1,2 & 67,3 \\
\hline $\begin{array}{l}\text { The company name includes the place } \\
\text { and field of business }\end{array}$ & 14 & 5,7 & 5,7 & 73,1 \\
\hline $\begin{array}{l}\text { The company name includes a } \\
\text { corporate name consisting of a } \\
\text { portmanteau of two or more words }\end{array}$ & 16 & 6,5 & 6,5 & 79,6 \\
\hline $\begin{array}{l}\text { The company name includes a product } \\
\text { brand }\end{array}$ & 49 & 20,0 & 20,0 & 99,6 \\
\hline The company name is a familial word & 1 & 4 & , 4 & \\
\hline Total & 245 & 100,0 & 100,0 & 100,0 \\
\hline
\end{tabular}

Sources: developed by the authors.

Table 5 sets out the degree of risk as perceived by the owners. The results in Table 5 provide the answer to RQ3: Do the owners of family companies perceive any risks in associating their family name with that of their family business?

Table 5. The perception of the degree of risk arising from the association of the family company's name with that of the family

\begin{tabular}{lcrcc}
\hline \multicolumn{1}{c}{ Risk of treats to reputation } & Frequency & Percent & Valid Percent & Cumulative Percent \\
\hline Without Risk & 8 & 3,3 & 3,3 & 3,3 \\
Low Risk & 30 & 12,2 & 12,2 & 15,5 \\
Middle Risk & 52 & 21,2 & 21,2 & 36,7 \\
High Risk & 155 & 63,3 & 63,3 & 100,0 \\
Total & 245 & 100,0 & 100,0 & \\
\hline
\end{tabular}

Sources: developed by the authors.

The findings from Table 5 show that $96.7 \%$ of the owners of family companies perceive a possible degree of risk based on the association of the family company's name with that of their family. $63.3 \%$ consider the risk to be high, while only $3.3 \%$ consider there to be no potential risk. RQ2 could be answered positively. The generational exchange has been ongoing in the Czech Republic in recent years. The names of the founder and the successor are closely associated with family companies and have been frequently discussed in this period of generational exchange. The findings in Table 4 show that over $43 \%$ of family companies have a family name included in their names. Any negative image about the family company's name or the family name can endanger the transition process. Reputational damage could have a potential influence on a company's value, a loss of customers, employee departures, and so on.

The following section of the research focuses on those family companies that are undergoing generational exchange. The following would be examined in this regard: a) establishing the company 
name and the process of generational exchange; b) the risks connected with the association of the company name with that of the family and generational exchange. Table 6 depicts the legend of the company name and the process of generational exchange. The findings in Tables 6 and 7 also answer RQ4: Do the owners of family companies perceive greater risks associated with the connection of the family name with the name of the family company in those family companies that are undergoing generational exchange?

a) The legend of the company name and the process of generational exchange.

Table 6. The legend of the company name and the process of generational exchange

\begin{tabular}{|c|c|c|c|c|}
\hline $\begin{array}{l}\text { Legend } \\
\end{array}$ & Not current & Underway & Transferred & Total \\
\hline $\begin{array}{l}\text { An invented corporate name, including } \\
\text { the company's legal form }\end{array}$ & 60 & 24,5 & 24,5 & 24,5 \\
\hline $\begin{array}{l}\text { The surname is included in the } \\
\text { company name + possibly the } \\
\text { company's legal form }\end{array}$ & 42 & 17,1 & 17,1 & 41,6 \\
\hline $\begin{array}{l}\text { The company name consists of the } \\
\text { founder's surname supplemented with } \\
\text { information on the participation of any } \\
\text { successors }\end{array}$ & 2 & 8 & ,8 & 42,4 \\
\hline $\begin{array}{l}\text { The company name represents the } \\
\text { family surname, the generations, and } \\
\text { the year of establishment }\end{array}$ & 1 & ,4 & , 4 & 42,9 \\
\hline $\begin{array}{l}\text { The company name includes the } \\
\text { founder's surname supplemented by } \\
\text { the field of business }\end{array}$ & 57 & 23,3 & 23,3 & 66,1 \\
\hline $\begin{array}{l}\text { The company name includes the } \\
\text { founder's surname supplemented by a } \\
\text { name, place, or field of business }\end{array}$ & 3 & 1,2 & 1,2 & 67,3 \\
\hline $\begin{array}{l}\text { The company name includes the place } \\
\text { and field of business }\end{array}$ & 14 & 5,7 & 5,7 & 73,1 \\
\hline $\begin{array}{l}\text { The company name includes a } \\
\text { corporate name consisting of a } \\
\text { portmanteau of two or more words }\end{array}$ & 16 & 6,5 & 6,5 & 79,6 \\
\hline $\begin{array}{l}\text { The company name includes a product } \\
\text { brand }\end{array}$ & 49 & 20,0 & 20,0 & 99,6 \\
\hline The company name is a familial word & 1 &, 4 & ,4 & \\
\hline Total & 245 & 100,0 & 100,0 & 100,0 \\
\hline
\end{tabular}

Sources: developed by the authors.

The findings from Table 6 show that $55.9 \%$ of the examined family companies are undergoing generational exchange. Notably, the family company's name includes the name of the founder and the successor, the company name, the generation, and the year. In turn, $100 \%$ of the family companies undergoing the transition to the successor have a familial word in the company name. Almost $67 \%$ of the family companies undergoing the transition to a successor have the founder's name, the place, and the field of business in the company name. Almost $60 \%$ of the family companies undergoing generational exchange have the founder's name, the year of establishment, or the field of business in the company's name. A certain degree of risk is associated with the process of generational exchange. Table 7 shows the perceived degree of risk involved with the association of a family name with that of a family company and the process of generational exchange. 
b) The risk of associating a family company's name with that of the family and the process of generational exchange.

Table 7. The risk of associating a family company's name with that of the family and the process of generational exchange

\begin{tabular}{lccrrr}
\hline Process/Risk & Without Risk & Low Risk & Middle Risk & High Risk & \multicolumn{1}{c}{ Total } \\
\hline Not current & $10,2 \%$ & $12,2 \%$ & $24,5 \%$ & $53,1 \%$ & $100,0 \%$ \\
Underway & $2,2 \%$ & $14,6 \%$ & $23,4 \%$ & $59,9 \%$ & $100,0 \%$ \\
Transferred & $0,0 \%$ & $6,8 \%$ & $13,6 \%$ & $79,7 \%$ & $100,0 \%$ \\
Total & $3,3 \%$ & $12,2 \%$ & $21,2 \%$ & $63,3 \%$ & $100,0 \%$ \\
\hline
\end{tabular}

Sources: developed by the authors.

Table 7 shows an upward trend in the degree of perceived risk from the association of a family company's name with that of the family in all family companies. The rate of high-risk perception due to the association of a family company's name with that of the family is $59.9 \%$ in family companies that are undergoing generational exchange. The highest degree of risk perception due to the association of a family company's name with that of the family in the examined family companies was found in family companies that have already transitioned, namely $79.7 \%$. In general, only $3.3 \%$ of the research sample of respondents do not perceive any such risk, $12.2 \%$ perceive the risk is low, $21.2 \%$ perceive a medium risk, and $63.3 \%$ perceive a high risk. Table 7 shows that it is impossible to state whether the family company owners undergoing generational exchange perceive a more significant risk. However, it has been proven that the family companies' owners have already transitioned perceive the most significant risk degree.

c) The risk of associating a family company's name with that of the family and the participation of several generations in the family company's management.

The following section deals with perception in the sense of the potential risk from the association of a family company with the family name concerning the involvement of several generations in the family company management. It will be possible to answer RQ5. Descriptive statistics of the frequency of the variables are subsequently performed (Table 8).

Table 8. A description of the frequency of the potential threat arising from the association of a family name with that of a family company according to the generational representation

\begin{tabular}{|c|c|c|c|c|c|c|c|}
\hline \multirow{2}{*}{ Risk } & \multirow{2}{*}{ Freq. } & \multicolumn{5}{|c|}{ Generation } & \multirow{2}{*}{ Total } \\
\hline & & 1. & 1. a 2. & 1., 2. a 3 & 2. & 2. a 3. & \\
\hline Without Risk & $\%$ & $\underline{20,0}$ & 0 & 7,5 & 4,3 & 1,9 & 3,3 \\
\hline Low Risk & $\%$ & $\overline{40,0}$ & 9,5 & 5,0 & 6,4 & 22,6 & 12,2 \\
\hline Middle Risk & $\%$ & 20,0 & 12,6 & $\underline{27,5}$ & $\underline{27,7}$ & 26,4 & 21,2 \\
\hline High Risk & $\%$ & 20,0 & 77,9 & 60,0 & $\underline{61,7}$ & 49,1 & 63,3 \\
\hline Total & $\%$ & 100,0 & $\overline{100,0}$ & 100,0 & $\overline{100,0}$ & $\overline{100,0}$ & 100,0 \\
\hline
\end{tabular}

Sources: developed by the authors.

The potential threat from the association of a family company's name with that of the family increases with the entry of new generations into a family company during the generational exchange. In turn, it could be subsequently placed at risk by that. $97 \%$ of the owners of family companies perceive a potential risk from the association of the family company's name with that of the family. Therefore, it is possible to answer RQ: Do the owners of family companies perceive a more significant risk from associating the family name with that of the family company in those family companies where several generations are involved in management? as follows. One-fifth of the family companies do not perceive any potential risk from the association of the family name with that of the family company. 
In contrast, the most significant frequency of perceived potential risk from the association of the family name with that of the family company was $40 \%$ in family companies with only the 1 st generation in management. The perceived potential risk from associating the family name with that of the family company was almost $78 \%$ in companies with the 1 st and 2 nd generations in the management. Therefore, it could be inferred that the perceived risk, in this case, is be associated with the intergenerational transfer's success (or lack thereof). Family companies with three generations together or only the 2nd or the 2nd and 3rd generations together displayed a medium level of perceived risk due to associating the family name with that of the family company. The Pearson correlation coefficient was used to ascertain the interdependencies of the five variables (Table 9).

Table 9. The matrix of variables

\begin{tabular}{|c|c|c|c|c|c|c|}
\hline & & 1. & 2. & 3. & 4. & 5. \\
\hline 1. & Legend & 1 & 1 & 1 & 1 & 1 \\
\hline 2. & Process &,- 064 &, $212^{* *}$ &,$- 215^{\star *}$ &,- 084 & \\
\hline 3. & Risk &,- 053 &,$- 259^{* *}$ &,- 093 & & \\
\hline 4. & Year of establishment &,- 071 &, $154^{*}$ & & & \\
\hline 5. & Generation &,- 005 & & & & \\
\hline
\end{tabular}

The results of the correlation analysis using the Pearson coefficient showed a weak interdependency between the variables. Without dependence, generation variables are related to Legend, Risk, and Year of the establishment. The Legend variable has no dependency on the others (the statistical evaluation would be discussed below (Table 10). A negative dependency has been shown between the Process of generational exchange and the Period of establishment variables. On the other hand, a positive dependency has been found between the Process of generational exchange and the Risk of associating the family company's name with that of the family variables and the Process of generational exchange and the Generations represented in the family company variables. The regression analysis was subsequently undertaken based on these results. The regression analysis was performed for the explained and explanatory variables. The defined variable is Risk of associating a family company's name with that of the family. The explanatory variables are Process, Generation, and Legend. The Generation variable has been included to correlate with the Process variable. The first step was the test for any possible exclusion of the variables due to collinearity.

Table 10. The exclusion of variables due to collinearity

\begin{tabular}{|c|c|c|c|c|c|c|}
\hline \multicolumn{2}{|c|}{ Model } & \multirow{2}{*}{$\begin{array}{l}\text { Beta In } \\
168^{b}\end{array}$} & $t$ & Sig. & $\begin{array}{l}\text { Partial } \\
\text { Correlation }\end{array}$ & $\begin{array}{l}\text { Collinearity Statistics } \\
\text { Tolerance }\end{array}$ \\
\hline 1 & Process & & 2,615 & ,009 & ,166 & \\
\hline & Generation & $-112^{b}$ & $-1,795$ & , 074 & -115 & 933 \\
\hline 2 & Legend &,$- 068^{b}$ & $-1,084$ & 279 &,- 070 & ,995 \\
\hline & Generation &,$- 137 c$ & $-2,206$ & ,028 &,- 141 &, 974 \\
\hline 3 & Legend &,$- 055^{c}$ &,- 877 & ,381 &,- 056 & ,988 \\
\hline & Legend &,$- 055^{d}$ &,- 884 & ,378 &,- 057 & ,988 \\
\hline
\end{tabular}

a. Dependent Variable: Risk

b. Predictors in the Model: (Constant), Year of establishment

c. Predictors in the Model: (Constant), Year of establishment, Process

d. Predictors in the Model: (Constant), Year of establishment, Process, Generation

Sources: developed by the authors. 
The Legend variable was excluded from the model due to collinearity. Collinearity: in statistics, the correlation between the predictor variables (or the independent variables) is such that it expresses a linear relationship in the regressive model. If the predictor variables are correlated in the same regressive model, they cannot independently predict the value of the dependent variable. They explain some of the same deviations in the dependent variable, which reduces their statistical significance. Collinearity becomes a problem in regression analysis if there is a high correlation or association between two potential predictor variables, which leads to a dramatic increase in the value $p$ (i.e., a reduction in the level of significance) of one predictor variable, if the further predictor is included in the regression model or if an inflationary factor with a high dispersion is designated. The inflation dispersion factor provides the degree of collinearity, so an inflation dispersion factor of 1 or 2 displays no collinearity, while a factor of 20 or above displays extreme collinearity. That means that it is possible to refute $\mathrm{H} 1$ : The family company name is connected with a risk that could arise from the association of the family name with that of the family company. This hypothesis worked with the Legend variable. The $\mathrm{H} 1$ hypothesis has not been proven due to the Legend variable's exclusion based on collinearity.

No interdependency has been proven based on the result of the Pearson coefficient calculation in the regression analysis for the Generations active in a family company's management variable and the Risk of associating the family company's name with that of the family variable: the variable's value is -0.093 , see Table 9. This value is not especially significant for any risks. Therefore, the Generations active in a family company's management negatively influence any potential risks, but this is only one of several factors in this context. As a result of the exclusion of the Legend variable (indicating the association of a family company's name with that of the family) due to collinearity, it is possible to state that the $\mathrm{H} 2$ hypothesis: The owners of family companies where several generations are in management are more aware of the risk of associating the family name with that of the family company than is the case where there is only one generation in the family company's management has not been proven. Stepwise regression, forward selection, the model. The explained variable - The Risk of associating the family company's name with that of the family, using the stepwise regression method and the forward selection method, works with all of the variables at once. The acquired data were analyzed according to the procedures of the vetted model used by Písař and Bílkova (2019).

Table 11. Variables Entered/Removeda

\begin{tabular}{clll}
\hline Model & Variables Entered & Variables Removed & Method \\
\hline 1 & Year of establishment & $\ldots \ldots$. & Stepwise ${ }^{*}$ \\
2 & Process & $\ldots \ldots .$. & Stepwise $^{*}$ \\
\hline & & Continued Table 11 \\
\hline 3 & Generation & $\ldots \ldots .$. & Stepwise \\
\hline a. Dependent Variable:The risk of associating a company name with a family name; ${ }^{*}$ (Criteria: Probability-of-F-
\end{tabular}
to-enter <= ,050, Probability-of-F-to-remove $>=, 100$ ).

Sources: developed by the authors.

Table 11 depicts the gradual inclusion of the examined variables in the model. The resulting model was further compiled following Table 12. Interpretation of the resulting model, for example, the selection regression coefficient Process $=0.234$ indicates that if the value of the explanatory variable Process increases by one degree, then assuming that the values of all other explanatory variables do not change. Then this change would increase the value of the explanatory variable on behalf of the family by an average of 0.234 in units of the variable explained. If the model is known, it could predict and influence the future development of variables. In this case, the determinants of Family business. The results are presented with the knowledge that the results of the significance of regression are, in some cases, zero. 
A., Tomaskova, R., Smietanski, M., Halouzka. The Interdependency Between a Family Company's Name and a Family Name

\begin{tabular}{|c|c|c|c|c|c|c|}
\hline Model & $\begin{array}{l}\text { Unstandardized } \\
\text { Coefficients B }\end{array}$ & Std. Error & $\begin{array}{l}\text { Standardized } \\
\text { Coefficients beta }\end{array}$ & $\begin{array}{l}\text { Standardized } \\
\text { Coefficients Beta }\end{array}$ & $t$ & Sig. \\
\hline \multirow[t]{2}{*}{1} & (Constant) & 2,874 & ,135 & & 21,228 & ,000 \\
\hline & $\begin{array}{l}\text { Year of } \\
\text { establishment }\end{array}$ &,- 123 & ,036 &,- 215 & $-3,434$ & ,001 \\
\hline \multirow[t]{3}{*}{2} & (Constant) & 2,360 & 238 & & 9,917 & 000 \\
\hline & $\begin{array}{l}\text { Year of } \\
\text { establishment }\end{array}$ &,- 098 & ,037 &,- 172 & $-2,680$ & , 008 \\
\hline & Process & ,210 & 080 & ,168 & 2,615 & ,009 \\
\hline \multirow[t]{4}{*}{3} & (Constant) & 2,608 & ,262 & & 9,970 &, 000 \\
\hline & $\begin{array}{l}\text { Year of } \\
\text { establishment }\end{array}$ &,- 102 & ,036 &,- 178 & $-2,801$ & ,006 \\
\hline & Process & ,234 & 080 & , 187 & 2,914 & ,004 \\
\hline & Generation &,- 090 &, 041 &,- 137 & $-2,206$ & ,028 \\
\hline
\end{tabular}

a. Dependent Variable: The risk of associating a company name with a family name

Sources: developed by the authors.

This fact opens up space for setting the scaling of the variable differently. It could be implicitly concluded that, for example, the involvement of members of specific generations would be affected by the year of the company's establishment. The longer a company is on the market, the older it is. Therefore, more generations are involved, depending on the life cycle of the family and the family business. Final model:

Risk of associating the company name with the family name $=2,608-$ $0,102 *$ Year of establishment $+0,234 *$ Process $-0,090 *$ Generation

At the end of the individual t-tests of Table 12, it could be stated that the above model is at the $5 \%$ significance level. An important finding follows from Table 13, where the overall F-test of the model with $n$ $=3$ explanatory variables is significant at the $1 \%$ level of significance.

Table 13. Model F test ANOVAa

\begin{tabular}{llccccc}
\hline Model & & Sum of Squares & df & Mean Square & F & Sig. \\
\hline 1 & Regression & 7,799 & 1 & 7,799 & 11,792 &, $001^{\mathrm{b}}$ \\
& Residual & 160,708 & 243 &, 661 & & \\
& Total & 168,506 & 244 & & &, $000^{\mathrm{c}}$ \\
2 & Regression & 12,216 & 2 & 6,108 & 9,458 & \\
& Residual & 156,290 & 242 &, 646 & & \\
& Total & 168,506 & 244 & & & \\
3 & Regression & 15,309 & 3 & 5,103 & 8,028 & \\
& Residual & 153,197 & 241 &, 636 & & \\
& Total & 168,506 & 244 & & & \\
& & & & & & \\
\end{tabular}

a. Dependent Variable: Risk

b. Predictors in the Model: (Constant), Year of establishment

c. Predictors in the Model: (Constant), Year of establishment, Process

d. Predictors in the Model: (Constant), Year of establishment, Process, Generation

Sources: developed by the authors. 
It is possible to assess $\mathrm{H} 3$ based on the conclusions of the correlation and regression analyses and the model mentioned above of the examined variables. The regression analysis and the compiled model show that the Process of generational exchange $(0.234)$ and the explained variable of the Risk of associating the family company's name with that of the family are significant factors for the transfer of a family company. The family company is associated with the family, and damage to the reputation could endanger the transition process or vice versa. A positive reputation could be the key to a successful transfer. It is clear from the model compiled for the explained Risk of associating the family company's name with that of the family variable that the Process of generational exchange variable at a statistically significant level of $5 \%$ significance initiates, identifies, and could influence the potential risks connected with the association of the family and the company during a generational transition. Increasing the credibility of the connection between the company and the family, which is primarily focused on any future generational transfer, would significantly increase the company's potential for success. This finding is important. The value of the Pearson coefficient of the correlation analysis for these variables is 0.212 . It indicates a positive interdependency between the variables (Table 9). Here, it is important when assessing the hypothesis to consider the fact that the Legend variable (the association of the family name with that of the family company) has been excluded due to collinearity (Table10). Hypothesis H3 cannot be considered to have been proven based on the facts stated above.

The discussion. It is prudent to discuss the factors presented in the research and comment on the findings of the descriptive statistics, the correlation, and regression analysis. Likewise, it is also necessary to support or refute the hypotheses' verification with arguments and compare the research findings mentioned above with those of the work of selected authors cited in the Literature Review.

Family companies often have the family name incorporated into their names. The family name is inherently associated with the family company's name, and the family is associated with the family company. Of the examined family companies, $43.2 \%$ include the name of the founder's family in their names. Family companies' names include the name of the founder's family, the field of business, or the fact that they are a family company. The link between the family name and the name of the family business often leads to an ambivalent view of both entities. This view, if negative, casts a bad light on the family company and the family itself. It brings risks in the form of a bad reputation, a loss of customers, employee departure, a fall in revenues and prestige, etc. Deephouse and Jaskiewicz (2013) spoke about negative attention and increasing credibility. They anticipated that a company's reputation would be increased if a family name were part of the company name. Kashmiri and Mahajan (2014) claimed that the founder's family name in a family company's name acts as a valuable company resource. This research has divided the composition of the names of family companies into 13 groups. For example, the company name only includes a name and a surname, or the company name includes a product brand. Besides, the names of the examined family companies only fell into ten of the groups. At the beginning of the research, the author anticipated that the Legend of the composition of a family company name variable would be potentially significant. The result of the correlation analysis is that the Pearson coefficient for this variable within the context of the other variables lies between the values of -0.005 and -0.071 (Table 9 ). It is not possible to speak of any interdependency among the variables in this case. After moving on to the regression analysis, this variable was excluded due to collinearity (a value of 0,988 ). As such, the variable was not included in the subsequent model. Given these statistical results, it would be necessary to look for a different method of examining the Legend of the composition of the family company name variable that could demonstrate its statistical significance and interdependencies. It would require another method of examination but not another direction of study. The correct direction of examination has been confirmed based on the descriptive statistics (Table 6), where it is evident what groups the family company names fall.

At present, most family companies are experiencing generational exchange. $55.9 \%$ of the examined family companies are undergoing this process. In most cases, the family company's name includes the 

Name

family name. In turn, more than half of them perceive a risk from the association of the family company's name and that of the family. One, two, or even three generations are involved in the management of these companies. The successor would need funds for the transfer of the company. The price that would be necessary during the transfer of the family company and the exit of the founder could also be influenced by the perception of the association of the family company with the family name. Dipietro (2015) judged that successorship is one of the most significant risks for family companies and likewise is a risk that can damage a family's reputation. According to Downing (2012), the considerable risks include sensitive matters of family relations and reputation caused by the connection between the family name and the company name. $97 \%$ of the examined family companies conceded the existence of possible risks. Visser and van Scheers (2018) spoke of risks that could not be monetarily enumerated, such as the threat to the ongoing competitiveness of the family company. This research has proven that the owners of family companies undergoing generational exchange do not perceive a greater level of risk. It has confirmed that the owners of family companies that have already transitioned perceive the most significant risk. It has not been statistically proven that the owners of companies where the generational exchange was ongoing were aware of any risk from the association of the family name.

Conclusions. Family companies are the backbone of state economies and basic service providers in the regions. One of their specific characteristics is an orientation towards the long-term, leading the family company towards an intergenerational handover. At that time, several generations could be active in a family company at the same time. A well-functioning family company and family constitute the foundation for a successful transfer. Every failure, case of disharmony, and a poor reputation could endanger the intergenerational process. It goes double for family companies.

The name of a family company often includes the name of the owning family and the field of business. Its name personifies each company. The significant degree of connection arising from the association of the family company with the owning family brings with its positive aspects and negative risks for both parties. Owners consider the family name in a family company name to constitute a certain risk. Any negative view of the family company or the family itself could lead to losing the good name and losing suppliers, customers, employees, prestige, and social status. In turn, it could irrevocably damage the process of intergenerational exchange. The interdependency between the intensity of the risk perception and the process of intergenerational exchange that more than half the family business is undergoing has been statistically proven. That involves a rising tendency in the perceived risk due to the association of a family company with the family name in all family companies. In the case of family companies undergoing generational exchange, a level of high-risk perception concerning the association of the family company's name with that of the family could be found in more than half the family companies. The highest level could be found in transitioned family companies, which amounts to more than two-thirds of family companies. Notably, the family companies' owners in the process of undergoing generational exchange perceived greater risk. However, it has been proven that the most significant level of risk is perceived by the owners of those family companies that have already transitioned. It is possible to speak of building a strong position for the successor, for whom any negative image could be undesirable.

On the other hand, only $3 \%$ of the respondents see this as being without any risk. One-fifth of family companies do not perceive any potential risk from the association of the family name with that of the family company according to the representation of generations in the family company management. Wherever only the 1 st generation is most prevalent in management, the perception of the potential risk from associating the family name with that of the family company is low. On the other hand, more than twothirds of family companies with the $1^{\text {st }}$ and $2^{\text {nd }}$ generations in management perceive this potential risk. In this case, the threat perception could be associated with the success (or lack thereof). The level of threat perception is average in family companies with three generations in the management or only the $2^{\text {nd }}$ or the $2^{\text {nd }}$ and $3^{\text {rd }}$ generations together. 
The exclusion of the variable for the risk perception from associating the name of a family company with the owning family due to collinearity means that all three hypotheses are containing this variable have been rejected. In this regard, there is the option of using a different method of investigation, which could demonstrate the statistical significance. It involves another method but not another direction of the investigation. The correct direction of investigation has been confirmed based on the data for the primary qualitative research and the result of the descriptive statistics. A successful transition to the following generation could be used as a tool to manage and increase their competitiveness. This research could be limited by the very answers of the respondents from the family companies. The limitation lies in the author's interpretation of the composition and contents of the name of the family company, the subjective replies of the respondents, which could have been overrated or underrated. They were made at a specific time in the life cycle of each family company and the family. The answers of the respondents have come from across the generations and include founders and successors. The views of the generations could be diametrically opposed.

Author Contributions: conceptualization, A. T. and R. S.; methodology, A. T.; software, M. H.; validation, M. H. and R. S; formal analysis, R. S.; investigation, A. T.; resources, A. T.; data curation, A. T. and R. S.; writing-original draft preparation, A. T.; writing-review and editing, A. T.; visualization, A. T.; supervision, A. T.; project administration, A. T.; funding acquisition, A. T.

Funding: The result was created in solving the student project Intergenerational transfer of family crafts - a challenge for the 4.0 phenomenon, No. 7427/2020/03 using objective-oriented support for specific university research of the University of Finance and Administration. The text can also be used to create a methodology within the project Family Businesses: Value Generators and Determining Value in the Succession Process TL02000434, which is VSFS a.s. co-researcher.

\section{References}

Adedayo, O. S., Olanipekun, O. J., \& Ojo, O. (2016). Planning for succession and firm's sustainability: Evidence from family owned businesses in Lagos and Ogun States, Nigeria. Issues in Business Management and Economics, 4(6), 63-69. [Google Scholar]

Alonso, A. D., \& O'Brien, S. (2017). Family firms' management decision to export/not to export: a resource-based view. Journal of Advances in Management Research, 14(3), 270-287. [Google Scholar] [CrossRef]

Aparicio, G., Basco, R., Iturralde, T., \& Maseda, A. (2017). An exploratory study of firm goals in the context of family firms: An institutional logics perspective. Journal of Family Business Strategy, 8(3), 157-169. [Google Scholar] [CrossRef]

Aries, P. H. (2016). What Drives International Competitiveness? An Empirical Test in Emerging Indonesian Market. Journal of Competitiveness, 8(4), 124. [Google Scholar]

Astrachan, C. B., Prügl, R., Hair, J. F., Barry, J., \& Babin, J. (2019). From Family Identity to Family Firm Image and Reputation: Exploring Facets of the Perception of Family Influence in Branding, Marketing, and Other Messaging. Journal of Family Business Strategy, 10(1), 1-68.Retrieved from [Link]

Babin, B. J., Astrachan, C. B., Botero, I. C., Hair, J. F., Prügl, R., Herrmann, J. L., ... \& Sarstedt, M. (2017). From Family Identity to Family Firm Image and Reputation: Exploring Facets of the Perception of Family Influence in Branding, Marketing, and Other Messaging. Journal of Family Business Strategy, 2(8), I-III. [CrossRef]

Bakoglu, R., \& Yıldırım, O. B. A. (2016). The role of sustainability in long term survival of family business: Henokiens revisited. Procedia-Social and Behavioral Sciences, 235, 788-796. [Google Scholar] [CrossRef]

Ball, R. (2017). Visualizing genealogy through a family-centric perspective. Information Visualization, 16(1), 74-89. [Google Scholar] [CrossRef

Basco, R. (2017). «Where do you want to take your family firm?» A theoretical and empirical exploratory study of family business goals. BRQ Business Research Quarterly, 20(1), 28-44. [Google Scholar] [CrossRef]

Benavides-Velasco, C. A., Quintana-García, C., \& Guzman-Parra, V. F. (2013). Trends in family business research. Small business economics, 40(1), 41-57. [Google Scholar] [CrossRef]

Brom, O., \& Řehak, J. (2015). SPSS-Prakticka analýza dat. Computer Press. [Google Scholar]

Cherchem, N. (2017). The relationship between organizational culture and entrepreneurial orientation in family firms: Does generational involvement matter?. Journal of family business strategy, 8(2), 87-98. [Google Scholar] [CrossRef]

Crystal, J. H. F. (2015). Family-owned Businesses Struggle to Manage Risks. Risk and Compliance Journal. Retrieved from [Link] 
A., Tomaskova, R., Smietanski, M., Halouzka. The Interdependency Between a Family Company's Name and a Family Name

Cucculelli, M., Le Breton-Miller, I., \& Miller, D. (2016). Product innovation, firm renewal and family governance. Journal of Family Business Strategy, 7(2), 90-104. [Google Scholar] [CrossRef]

Daniell, M. H., \& McCullough, T. (2013). Family wealth management. Singapore: John Wiley and Sons Singapore Pte. Ltd [Google Scholar]

Darlington, R. B., \& Hayes, A. F. (2016). Regression Analysis and Linear Models: Concepts, Applications, and Implementation. Guilford Publications. [Google Scholar]

Daspit, J. J., Holt, D. T., Chrisman, J. J., \& Long, R. G. (2016). Examining family firm succession from a social exchange perspective: A multiphase, multistakeholder review. Family Business Review, 29(1), 44-64. [Google Scholar] [CrossRef]

De Clercq, D., \& Belausteguigoitia, I. (2015). Intergenerational strategy involvement and family firms' innovation pursuits: The critical roles of conflict management and social capital. Journal of Family Business Strategy, 6(3), 178-189. [Google Scholar] [CrossRef]

Deephouse, D. L., \& Jaskiewicz, P. (2013). Do family firms have better reputations than non-family firms? An integration of socioemotional wealth and social identity theories. Journal of management Studies, 50(3), 337-360. [Google Scholar] [CrossRef]

Dehlen, T., Zellweger, T., Kammerlander, N., \& Halter, F. (2014). The role of information asymmetry in the choice of entrepreneurial exit routes. Journal of Business Venturing, 29(2), 193-209. [Google Scholar] [CrossRef]

Di Serio, L. C., de Oliveira, L. H., \& Siegert Schuch, L. M. (2011). Organizational risk management: A case study in companies that have won the Brazilian Quatity Award Prize. Journal of technology management \& innovation, 6(2), 230-243. [Google Scholar] [CrossRef]

Dipietro, B. (2015). Family-owned Businesses Struggle to Manage Risks. Retrieved from [Link]

Downing, A. (2012). Risk management for financial families. Wells Fargo Bank, NA: Wells Fargo \& Company.

Firfiray, S., Cruz, C., Neacsu, I., \& Gomez-Mejia, L. R. (2018). Is nepotism so bad for family firms? A socioemotional wealth approach. Human Resource Management Review, 28(1), 83-97. [Google Scholar] [CrossRef]

Gavurova, B., Ivankova, V., Rigelsky, M., \& Prívarova, M. (2020). Relations Between Tourism Spending and Global Competitiveness-an Empirical Study in Developed OECD Countries. Journal of Tourism and Services, 11(21), 38-54. [Google Scholar] [CrossRef]

Hiebl, M. R. (2012). Risk aversion in family firms: what do we really know?. Journal of Risk Finance, 14(1), 49-70. [Google Scholar] [CrossRef]

Hrytsenko, L. L., Roienko, V., \& Boiarko, I. M. (2018). Institutional background of the role of state in investment processes activation. Financial and credit activities: problems of theory and practice, 1(24), 338-344. [CrossRef]

Kashmiri, S., \& Mahajan, V. (2010). What's in a name?: An analysis of the strategic behavior of family firms. International Journal of Research in Marketing, 27(3), 271-280. [Google Scholar] [CrossRef]

Kashmiri, S., \& Mahajan, V. (2014). A rose by any other name: Are family firms named after their founding families rewarded more for their new product introductions?. Journal of Business Ethics, 124(1), 81-99. [Google Scholar] [CrossRef

Kenyon-Rouvinez, D., Ward, J. L., \& Ogrocký, J. (2016). Rodinna firma: Jak vybudovat, úspěsně vést a předat rodinný podnik.

Barrister \& Principal.

Kharazishvili, Y., Kwilinski, A., Grishnova, O., \& Dzwigol, H. (2020). Social Safety of Society for Developing Countries to Mee Sustainable Development Standards: Indicators, Level, Strategic Benchmarks (with Calculations Based on the Case Study of Ukraine). Sustainability, 12(21), 8953. [CrossRef

Kroslakova, N. M. (2020). Rodinné podnikanie ako významna zložka ekonomických aktivit v hospodarstve Slovenska. Zlín:

Radim Bačuvčík - VeRBuM. [Google Scholar]

Kupec, V., Lukač, M., Písař, P., \& Gubíniova, K. (2020). Increasing Personnel Competencies in Museums with the Use of

Auditing and Controlling. Sustainability, 12(24), 10343. [Google Scholar] [CrossRef]

Kuznyetsova A. Ya., Zherebylo I. V., Klipkova O. I., Kozmuk N. I. (2019). Creation of the value of national enterprises with the help of the innovation centers in the cluster formations. Financial and credit activities: problems of theory and practice, 2(29), 391 . 402. [Google Scholar] [CrossRef]

Kwilinski, A. (2018). Mechanism of formation of industrial enterprise development strategy in the information economy. Virtual Economics, 1(1), 7-25. [CrossRef]

Kwilinski, A., \& Kuzior, A. (2020). Cognitive Technologies in the Management and Formation of Directions of the Priority Development of Industrial Enterprises. Management Systems in Production Engineering, 28(2), 119-123. [CrossRef]

Lipitz, E., \& Hauser, B. R. (2016). Trusts and Estates: Managing Risk in Family Businesses.

Means, B. (2016). Wealth inequality and family businesses. Emory Law Journal, 65(4), 937-986. Retrieved from [Link]

Meneses, R., Coutinho, R., \& Pinho, J. C. (2014). The impact of succession on family business internationalisation. Journal of

Family Business Management, 4(1), 24. [Google Scholar] [CrossRef]

MPO. (2019b). Tiskové zpravy. Rodinné podniky se dočkaly, vlada schvalila definici rodinného podnikaní. Retrieved from [Link MPO.(2019a). Tiskové zpravy. Komplexni podpora rodinných firem přpravena. Počita mimo jiné s bezúročnými pujčkami a zvýhodněnými zarukami. Retrieved from [Link]

Mura, L. (2020). Innovations And Marketing Management Of Family Businesses: Results Of Empirical Study. Internationa Journal of Entrepreneurial Knowledge, 8(2), 56-66. [Google Scholar] [CrossRef] 


\section{A., Tomaskova, $R$., Smietanski, M., Halouzka. The Interdependency Between a Family Company's Name and a Family Name}

Orgonas, J., Nad'ova Kroslakova, M., \& Rak, P. (2020). Franchising: (A Theoretical Approach). Uherské Hradistě: Akademie krizového rízení a managementu.

Pekerşen, Y., \& Tugay, O. (2020). Professional satisfaction as a key factor in employee retention: A case of the service sector. Journal of Tourism and Services, 11(20), 1-27. [Google Scholar] [CrossRef]

Petlina, A., \& Korab, V. (2015). Family Business in the Czech Republic: Actual Situation. Trendy Ekonomiky a Managementu, 9(23), 32. [Google Scholar]

Petru, N., Havliček, K., \& Tomaskova, A. (2018). Comparison of marketing vitality of family and non-family companies doing business in Czech republic. Economics \& Sociology, 11(2), 138-156. [Google Scholar] [CrossRef]

Petru, N., Kramolis, J., \& Stuchlik, P. (2020). Marketing Tools in the Era of Digitization and Their Use in Practice by Family and Other Businesses. E\&M Economics and Management, 23(1): 197-212. [Google Scholar] [CrossRef]

Pisar, P., \& Bilkova, D. (2019). Controlling as a tool for SME management with an emphasis on innovations in the context of Industry 4.0. Equilibrium. Quarterly Journal of Economics and Economic Policy, 14(4), 763-785. [Google Scholar]

Schmidts, T., \& Shepherd, D. (2015). Social identity and family business: exploring family social capital. Journal of Family Business Management, 5(2), 157. [Google Scholar] [CrossRef

Servus, S., Elischer, D., \& Horaček, T. (2018). Aktualni otazky nastupnictvi prì rodinném podnikaní. Wolters Kluwer.

Smith, M. (2020). Effective Leadership In Online Small Businesses: An Exploratory Case Study. International Journal of Entrepreneurial Knowledge, 8(2), 27-41. [Google Scholar] [CrossRef]

Tagiuri, R., \& Davis, J. (1996). Bivalent attributes of the family firm. Family business review, 9(2), 199-208. [Google Scholar] [CrossRef]

Tran, M. (2011). Robustness of two formulas to correct pearson correlation for restriction of range. Georgia State University Digital Archive @ GSU, 1-2. Retrieved from [Link]

Visser, T., \& van Scheers, L. (2018). Can family business managers manage family business risks?. Management: Journal of Contemporary Management Issues, 23(1), 123-137. [Google Scholar] [CrossRef]

Андреа Томаскова, Ph.D., Університет фінансів та управління, Чеська Республіка

Роман Смієтанський, Ph.D., Опольський політехнічний університет, Польща

Мирослав Галузька, Університет фінансів та управління, Чеська Республіка

Вплив особистості на бренд-неймінг сімейного бізнесу

Бренд сімейного бізнесу персоніфікує його на ринку пов'язуючи з особистістю ї̈ власника. У статті проаналізовано специфіку процесу правонаступництва поколінь у сімейних компаніях Чеської Республіки, а також систематизовано основні проблеми та шляхи їх вирішення. Метою даної статті $є$ виявлення та обґрунтування можливих ризиків впливу особистості на бренд-неймінг сімейного бізнесу. Авторами узагальнено можливі ризики функціонування сімейного бізнесу за умови участі представників сім'ї в менеджменті, а також спадковим правонаступництвом сімейного бізнесу. Детерміновану вибірку даних сформовано на основі результатів опитування 245 власників сімейних підприємств Чеської Республіки. Для формування вибірки дослідження проведено круглі столи та дискусії у період з 2017 року по 2019 рік. Методологію дослідження засновано на кореляційному та регресійному аналізах. За результатами дослідження авторами зроблено висновку, що власники сімейного бізнесу вважають потенційним ризиком асоціацію компанії з їх особистістю. Будь-яке негативне ставлення до сімейної компанії може негативно віддзеркалитись на сім'ю, тоді як негативне ставлення до сім'ї погіршує репутацію компанії. Це у свою чергу провокує відтік споживачів та працівників. Авторами зазначено, що це також може негативно вплинути на процес правонаступництва за умови спадкоємстві від одного покоління до іншого. Емпіричні результати аналізу згенеровано вибірки даних засвідчили статистично значущий взаємозв'язок між рівнем сприйняттям ризику та спадковим правонаступництвом сімейного бізнесу. Враховуючи отримані результати, авторами визначено, що високий ступінь сприйняття ризику характерний для сімейних компаній зі спадковим правонаступництвом. Перспективами подальших досліджень $€$ аналіз статистичної значущості за умови виключення змінної асоціації назви сімейної компанії із особистістю через високий ступінь їх колінеарності.

Ключові слова: назва компанії, кореляційний аналіз, Чеська Республіка, сімейний бізнес, прізвище, покоління, передача із покоління в покоління, регресійний аналіз. 